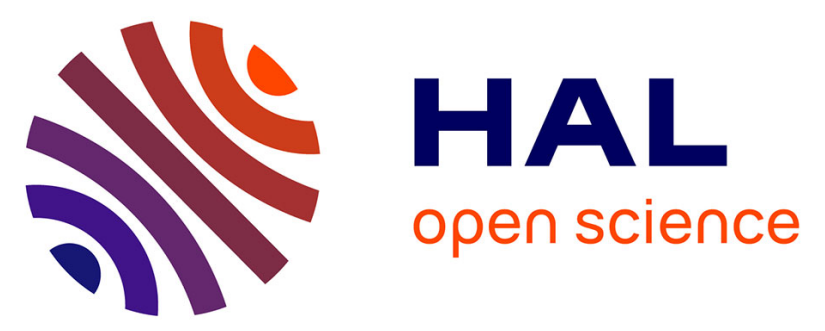

\title{
ENERGETIC PERFORMANCE OF A GREEN ROOF IN THE TROPICAL ENVIRONMENT OF LA REUNION ISLAND (INDIAN OCEAN)
}

Teddy Jeannick Libelle, Dominique Morau, Alexandre Clain, François Garde

\section{- To cite this version:}

Teddy Jeannick Libelle, Dominique Morau, Alexandre Clain, François Garde. ENERGETIC PERFORMANCE OF A GREEN ROOF IN THE TROPICAL ENVIRONMENT OF LA REUNION ISLAND (INDIAN OCEAN). Solar World Congress 2011, ISES, Aug 2011, Kassel, Germany. hal01111526

\author{
HAL Id: hal-01111526 \\ https://hal.science/hal-01111526
}

Submitted on 1 Feb 2015

HAL is a multi-disciplinary open access archive for the deposit and dissemination of scientific research documents, whether they are published or not. The documents may come from teaching and research institutions in France or abroad, or from public or private research centers.
L'archive ouverte pluridisciplinaire HAL, est destinée au dépôt et à la diffusion de documents scientifiques de niveau recherche, publiés ou non, émanant des établissements d'enseignement et de recherche français ou étrangers, des laboratoires publics ou privés. 


\title{
ENERGETIC PERFORMANCE OF A GREEN ROOF IN THE TROPICAL ENVIRONMENT OF LA REUNION ISLAND (INDIAN OCEAN)
}

\author{
Teddy Libelle, Dominique Morau, Alexandre Clain, François Garde \\ Laboratory P.I.M.E.N.T, Department of Environment and Building Sciences \\ University of La Reunion, Tampon, La Reunion (France) \\ Tel: 2626926539 35, Fax: 262262962859 \\ E-mail: teddy.libelle@univ-reunion.fr
}

\begin{abstract}
The green roof technology provides environmental benefits by protecting the base roof membrane of buildings against solar radiation and temperature fluctuations and by helping to reduce building's energy consumption by direct shading. Although several investigations have been performed to explore the energy performance of vegetated roofs as natural cooling devices, there is a lack of data concerning the green roof potential in the southern hemisphere. The aim of our work was to evaluate for the first time the performance of a green roof in La Reunion Island (Indian Ocean) influenced by a tropical humid climate. A green roof based on three kinds of vegetation, namely Plectranthus neochilus, Kalanchoe longiflora and Sedum reflexum species was compared to a reference bituminous roof during the summer season. The green roof performance was explored by evaluating its effect on temperature fluctuations and heat fluxes. The results showed that the presence of plants led to a decrease in temperature reaching $6.7 \pm 0.1{ }^{\circ} \mathrm{C}$ under the green roof. Each plant also contributed to a low heat flux exchange through the green roof. Indeed, Sedum presented an average heat flux exchange of $1.4 \pm 0.3 \%$ as compared to Plectranthus $(2.3 \pm 0.2 \%)$ and Kalanchoe $(2.2 \pm 0.4 \%)$. Moreover, Sedum also led to a higher restitution of heat gain (63\%) than Plectranthus (54\%) and Kalanchoe (51\%). Finally, the determination of major parameters including U-value, R-value and k-value, demonstrated the thermal and energetic behavior of the green roof and helped to show Sedum properties for a green roof based in the tropical environment of La Reunion Island. To conclude, this study has evaluated for the first time the thermal and energetic performance of a green roof in an Indian Ocean area. Our results contribute to highlight Sedum benefits for a vegetated roof in such an area. Further investigations will be needed to assess if the green roof technology provides a very effective solution for building energy savings in cities under a tropical humid climate.
\end{abstract}

\section{Introduction}

Green roof technology presents very interesting advantages for the protection of the base roof membrane of buildings against solar radiation and temperature fluctuations and for the reduction of building's energy consumption by direct shading (Castleton, et al. 2010; Kumar and Kaushik, 2005; Niachou et al., 2001; Theodosiou, 2003). A green roof can be defined as a complex multilayer envelop component involving many heat transfer phenomena. It usually includes the following layers: a water-proofing membrane, a drainage layer, a filter membrane, a substrate layer and plants. According to the composition and the thickness of the substrate layer, extensive and intensive green roofs can be defined. An extensive green roof is characterized 
by a thin substrate layer with a low planting level, whereas an intensive green roof has a thicker substrate layer allowing the use of deeper rooting plants such as trees. The performance of a green roof is affected by many parameters such as thermal properties of the layers and the substrate, plant species covering the roof and, of course, the climatic conditions (Getter et al., 2009; Ould-Boukhitine et al., 2011).

Several studies proposed green roof models in the northern hemisphere and highlight the thermal contribution of vegetated roofs and their performance to reduce heat fluxes in hot conditions (Lazzarin et al., 2005; MacIvor and Lundholm, 2011; Palomo, 1999; Spala et al., 2008). Wong et al. (2003a, 2003b) mainly explored the thermal contribution of a green roof in the tropical environment of Singapore through an experimental test done before and after the construction of a rooftop garden. Measurements showed that vegetation decreased the roof temperature from $57^{\circ} \mathrm{C}$ to $36^{\circ} \mathrm{C}$. However, there is still a lack of data on green roof technology advantages as natural cooling devices in the southern hemisphere.

The objective of this paper was to propose an experimental study of the extensive green roof in La Reunion, a French island located in the Indian Ocean, under a tropical humid climate in south hemisphere. This experimental green roof based on three kinds of vegetation, namely Plectranthus neochilus, Kalanchoe longiflora and Sedum reflexum species, was compared to a reference bituminous roof during the summer season. The green roof performance was explored by evaluating its effect on temperature fluctuations and heat fluxes.

\section{Materials and Methods}

\subsection{Green roof description}

The experimental green roof consists of a water-proofing membrane (an elastomer bilayer specially designed to resist root penetration), a drainage layer (a layer of $40 \mathrm{~mm}$ to facilitate the water to flow into storm drains while providing additional water retention), a filter membrane (a nonwoven synthetic fibre layer preventing clogging of the drainage layer by fine substrate particles), a substrate layer (a $80 \mathrm{~mm}$ layer, developed and produced in La Reunion Island and adapted to tropical climatic conditions to provide optimal and constant permeability, resistance to erosion and density of green roofing) and plants (Fig. 1).

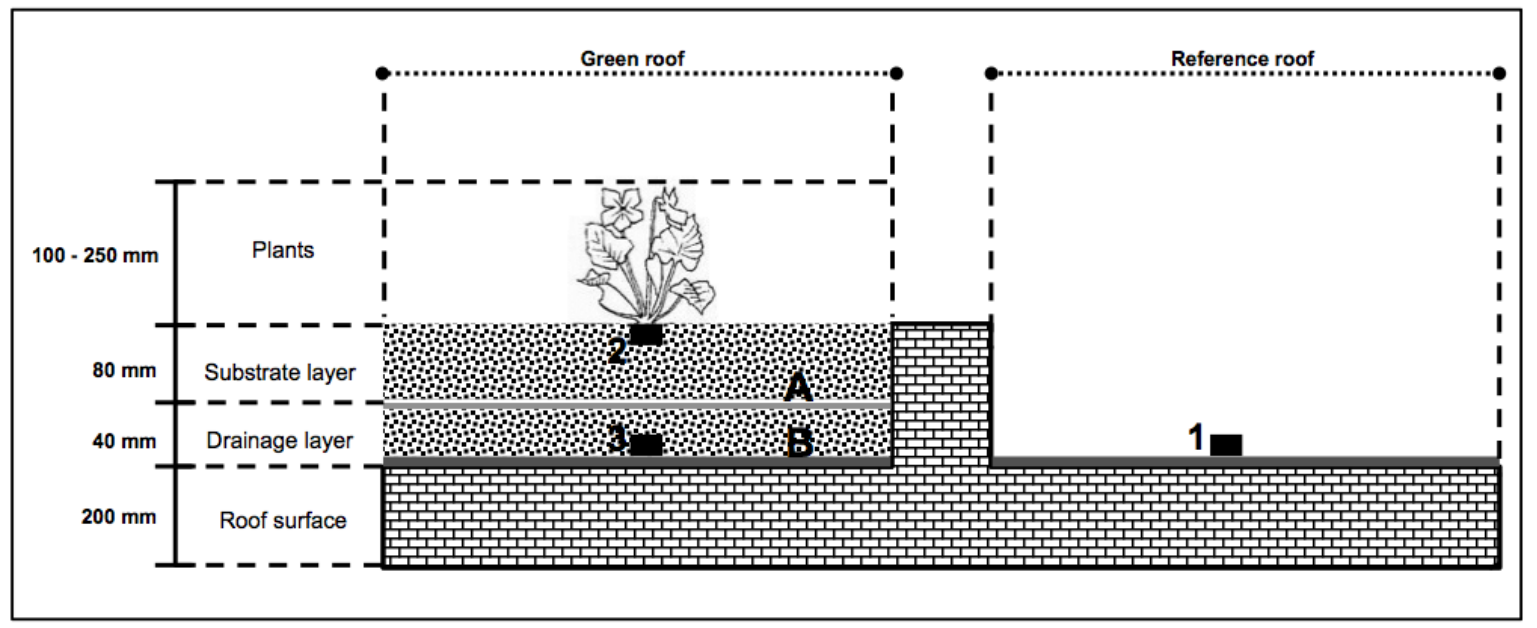

Fig.1: Green roof composition. As compared to the reference bituminous roof, the green roof is composed of plants, a substrate layer, a filter membrane (A), a drainage layer and a water-proofing membrane (B). Thermocouples were installed at the reference roof surface (1), and at the green roof surface (2) or at the depth of $120 \mathrm{~mm}(3)$. 
The green roof is also characterized by a maximal weight of $170 \mathrm{~kg} / \mathrm{m}^{2}$ and a water retention capacity reaching $40 \mathrm{~L} / \mathrm{m}^{2}$. A bituminous roof is located nearby the green roof and is used as a reference. Both the reference roof and the green roof have no slope and the same area $\left(54 \mathrm{~m}^{2}\right)$. Three plant species are tested, namely Plectranthus neochilus, Kalanchoe longiflora and Sedum reflexum, which are succulents. These plants are known to easily grow and to store water in their leaves, making them highly drought resistant. The average plant cover was $30 \%$ of the whole roof area. The plant cover for Sedum is $38 \%$ followed by Plectranthus (34\%) and Kalanchoe (28\%). This experimental green roof was installed in August-September 2010 on a building with a thermal insulation beneath the roof and which is occupied during working hours. It is located in Saint-Pierre city $\left(21^{\circ} 19^{\prime} \mathrm{S}, 55^{\circ} 28^{\prime} \mathrm{E}\right)$ in the south of La Reunion Island. The daily average temperature of ambient air is from $19.1^{\circ} \mathrm{C}$ to $33.2^{\circ} \mathrm{C}$; the minimal average temperature is $17.2^{\circ} \mathrm{C}$ during the dry season in the winter time and the maximal temperature is $35.8^{\circ} \mathrm{C}$ for the rainy season during the summer period.

\subsection{Sampling and analysis}

All measurements were performed from October 2010 to February 2011 representing a five month-period from the end of the winter season to the summer time in La Reunion Island. The site is equipped with a meteorological station connected to a data acquisition system allowing to examine external parameters such as rain data, air temperature and relative humidity, wind direction and speed, global horizontal solar radiation and air pressure. A set of sensors were also used for monitoring the specific green roof parameters, namely type $\mathrm{T}$ thermocouples for measuring surface temperature and green roof component temperature (between drainage layer and water-proofing membrane) as well as a sensor for evaluating heat fluxes through the green roof (HFP01 plate soil heat flux). All sensors were connected to a data acquisition system (CR 3000) supplied by a multiplexer (AM16/32B), allowing the monitoring of each parameter every $1 \mathrm{~min}$. Then, data were transferred via a RS232 port on a computer for processing (MS Excel and MatLab). For temperature measurements, thermocouples were installed at two levels within the green roof: at the green roof surface (GR Surface) and at $120 \mathrm{~mm}$ depth in the green roof (GR at $120 \mathrm{~mm}$ ). Some thermal sensors were also used to measure the temperature of the reference bituminous roof (RR surface) as well as the ambient air temperature.

\section{Results and discussion}

\subsection{Effect of the green roof on temperature fluctuations}

During the experimental period, the maximum ambient air temperature was $28.7 \pm 0.4^{\circ} \mathrm{C}$ and the maximum temperature of the reference roof reached $73.5 \pm 1.4^{\circ} \mathrm{C}$. The presence of plants significantly decreased the temperature of the roof surface (between the RR surface and the GR Surface) whatever their species. Indeed, results obtained over the experimental five-month period showed that the maximum temperature measured under the three species of plants reached an average of $34.8 \pm 0.6^{\circ} \mathrm{C}$. Accordingly, Wong et al. (2003a) reported that the maximum temperature measured under different kinds of vegetation in Singapore, which is also influenced by a tropical environment but under an equatorial climate, was closed to $36.0^{\circ} \mathrm{C}$. 
As shown on Tab. 1, plants were also able to induce a decrease in temperature fluctuations between the GR Surface and the GR at $120 \mathrm{~mm}$. The average values of temperature differences were of $6.8 \pm 1.4^{\circ} \mathrm{C}$ for Plectranthus, $6.5 \pm 0.9^{\circ} \mathrm{C}$ with Kalanchoe and $6.7 \pm 0.3^{\circ} \mathrm{C}$ for Sedum. Thus, the presence of plants resulted in an average value of temperature loss close to $6.7 \pm 0.1^{\circ} \mathrm{C}$ under the green roof. A similar median fluctuation of 5.0-7. $0^{\circ} \mathrm{C}$ was previously reported (Liu and Baskaran, 2003). Our results clearly demonstrate for the first time, the thermal performance of an extensive green roof developed in the Indian Ocean area under a tropical and humid climate. This study also shows that the three kinds of plants selected exhibit a significant ability to decrease the temperature at the green roof surface as well as inside the green roof.

Tab. 1: Variation of the monthly mean values of temperature between the green roof surface and the green roof at $120 \mathrm{~mm}$ from October 2010 to February 2011.

\begin{tabular}{lccc}
\hline \multicolumn{4}{c}{ Temperature differences between GR Surface and GR at $120 \mathrm{~mm}\left({ }^{\circ} \mathrm{C}\right)$} \\
\hline & Plectranthus & Kalanchoe & Sedum \\
\hline October & $9.2 \pm 2.1$ & $8.0 \pm 1.3$ & $8.0 \pm 2.5$ \\
November & $11.2 \pm 0.5$ & $9.0 \pm 2.6$ & $6.8 \pm 0.6$ \\
December & $5.7 \pm 0.5$ & $4.6 \pm 1.1$ & $6.2 \pm 0.9$ \\
January & $3.6 \pm 1.0$ & $4.8 \pm 0.6$ & $6.1 \pm 0.6$ \\
February & $4.6 \pm 0.2$ & $5.9 \pm 0.2$ & $6.3 \pm 0.5$ \\
\hline
\end{tabular}

\subsection{Effect of the green roof on heat flux variations}

Fig.2 illustrates the global solar radiation values (Fig. 2 a) and the comparison of heat flux transferred through the different green roof components according to the plant species (Fig. 2b) on three typical days in January. Whereas the mean value of maximum global solar radiation on three days was $1165.7 \pm 43.3 \mathrm{~W} / \mathrm{m}^{2}$, the maximum heat flux transferred through Plectranthus green roof surface was $27.7 \pm 2.2 \mathrm{~W} / \mathrm{m}^{2}$, leading to determine a transmitted heat flux exchange of $2.4 \pm 0.2 \%$. With Kalanchoe, the maximum heat flux reached a mean value of $28.8 \pm 2.7 \mathrm{~W} / \mathrm{m}^{2}$ that corresponded to a $2.5 \pm 0.3 \%$ of transmitted heat flux. For Sedum, it appeared a mean value of heat flux at $16.6 \pm 1.7 \mathrm{~W} / \mathrm{m}^{2}$, resulting into a heat flux exchange of $1.4 \pm 0.2 \%$ and suggesting that energy performance of Sedum is better than those of Plectranthus and Kalanchoe.

During all the experimental five-month period, our study also shows that Sedum green roof presented an average heat flux exchange of $1.4 \pm 0.3 \%$ as compared to Plectranthus $(2.3 \pm 0.2 \%)$ and Kalanchoe $(2.2 \pm 0.4 \%)$ green roofs. This result agrees with the data published by Feng et al. (2010) establishing a heat flux exchange of $1.2 \%$ for Sedum green roof. Here, the higher performance of Sedum could be related to its higher sunshading effect as well as its higher ability to grow more quickly than Plectranthus and Kalanchoe. Accordingly, in a three years study by the University of Michigan, the drought resistance of a wide range of Sedum plants was compared to 18 native and non-native plants. It was concluded that Sedum plants were the most suited to unirrigated roofs in Michigan's climate, as all Sedum plants survived while other species had significant high mortality rates. Such a high drought resistance of Sedum plants is attributed to their ability, as succulents, to easily store water in their leaves (Getter et al., 2009). Lazzarin et al. (2005) compared the energetic exchange of a Sedum dry or wet green roof with a traditional roof in the north-east of Italy during the summer season and also reported a significant lower heat flux exchange for Sedum (0.4-1.8\%) than for a 
traditional roof $(4.4 \%)$. For Wong et al. (2003a), the thermal protection of plants also highly depends on their leaf area index (LAI) since lower temperatures were found under dense trees and shrubs as compared to sparse foliages.

a.

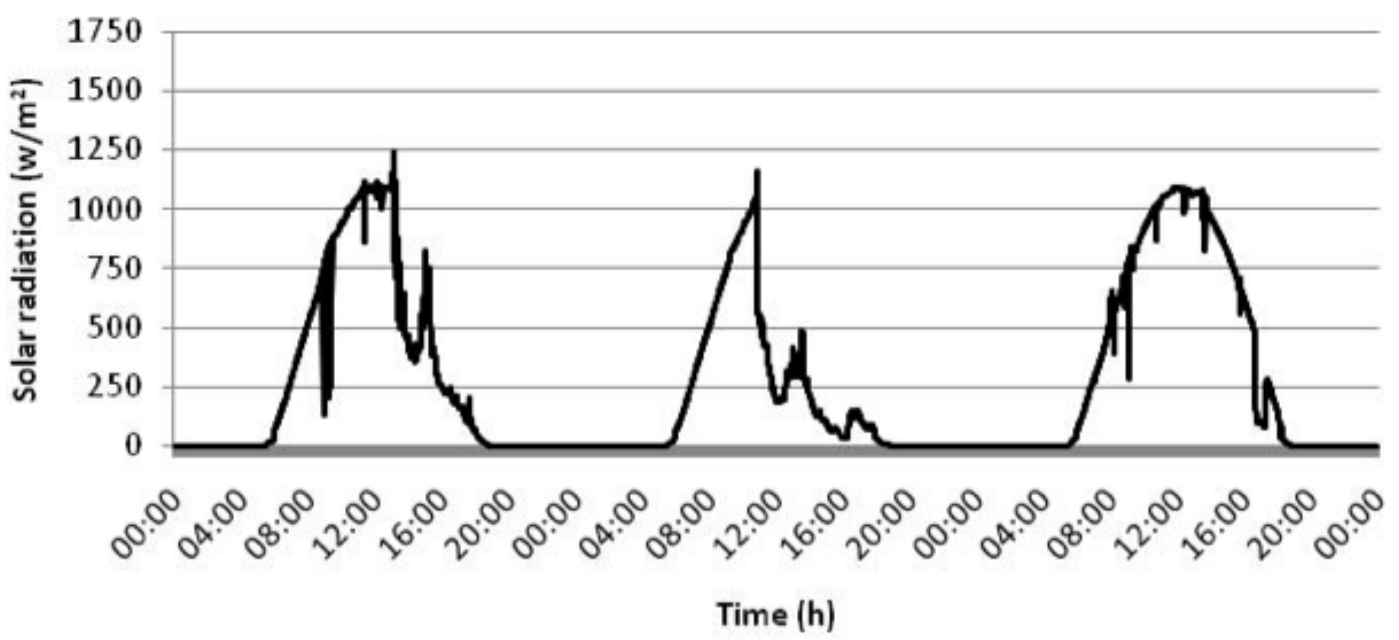

b.

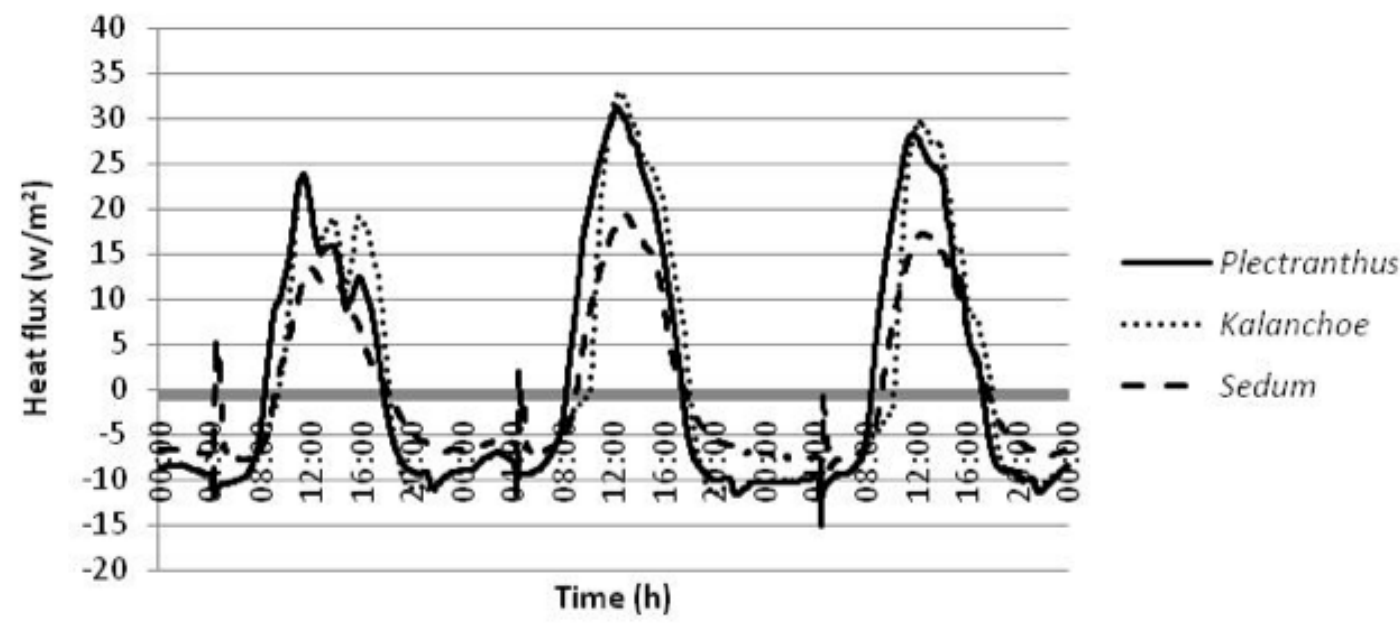

Fig. 2: Effect of the green roof on heat flux variations in January 2011. Global solar radiations (a) and heat fluxes (b) were measured on three typical days.

As the green roof energy performance depends on its ability to reduce the heat gain, we measured the heat gain/loss per square meter over the five-month period. Considering that the total solar radiation did not significantly change during this period $\left(1215.9 \pm 32.0 \mathrm{~W} / \mathrm{m}^{2}\right)$, it could be observed that the presence of the green roof was associated with an average total heat gain decreasing over the time. Indeed, from October to February, the total heat gain decreased from $1095.6 \pm 158.7-760.4 \pm 42.0 \mathrm{~kJ} / \mathrm{m}^{2}$ for the green roof with Plectranthus. For Kalanchoe green roof, the total heat gain reduced from $858.0 \pm 90.4-657.3 \pm 58.8 \mathrm{~kJ} / \mathrm{m}^{2}$. With Sedum green roof, the total heat gain also significantly decreased from 795.6 $\pm 174.9-443.6 \pm 99.7 \mathrm{~kJ} / \mathrm{m}^{2}$. Such a decrease in the total heat gain value observed with the green roof can be explained by the growth of plants offering a higher coverage and a better roof membrane protection. Similarly, several literature data 
reported the ability of green roofs to reduce the proportion of solar radiation that reaches the roof structure as plants create a shadow effect on the soil layer (Kumar and Kaushik, 2005; Lui and Minor, 2011; Theodosiou, 2003; Wong et al. 2003b). Regarding the total heat loss, the experimental green roof was also able to efficiently restitute heat fluxes. Our data demonstrated that the green roof with Sedum led to a higher restitution of heat gain $(63 \%)$ than the green roof with Plectranthus $(54 \%)$ and Kalanchoe (51\%).

\subsection{Evaluation of the green roof thermal parameters}

In order to better characterize the energy performance of a green roof newly developed, it is required to determine the conduction heat transfer coefficient (U-value), the thermal resistance value (R-value) and the thermal conductivity coefficient (k-value). Tab. 2 reports the results we obtained at the end of the experimental five-month period.

Tab. 2: Evaluation of the green roof thermal parameters. The conduction heat transfer coefficient (U-value), thermal resistance value (R-value) and thermal conductivity coefficient (k-value) are indicated for February 2011.

\begin{tabular}{lccc}
\hline & $\mathrm{U}\left(\mathrm{W} / \mathrm{m}^{2} \cdot \mathrm{K}\right)$ & $\mathrm{k}(\mathrm{W} / \mathrm{m} \cdot \mathrm{K})$ & $\mathrm{R}\left(\mathrm{m}^{2} \cdot \mathrm{K} / \mathrm{W}\right)$ \\
\hline Plectranthus & $5.46 \pm 0.43$ & $1.75 \pm 0.05$ & $0.19 \pm 0.01$ \\
Kalanchoe & $3.39 \pm 0.59$ & $1.25 \pm 0.07$ & $0.32 \pm 0.06$ \\
Sedum & $2.15 \pm 0.22$ & $0.47 \pm 0.03$ & $0.47 \pm 0.05$ \\
\hline
\end{tabular}

It appears that the green roof with Sedum presents a U-value of $2.15 \pm 0.22 \mathrm{~W} / \mathrm{m}^{2} . \mathrm{K}$ which is significantly lower than that calculated with Plectranthus and Kalanchoe species. Consequently, Sedum offers the highest thermal resistance value, as R-value is inversely proportional to U-value. To determine the thermal conductivity coefficient ( $\mathrm{k}$-value), it is essential to measure the total depth of the green roof (soil + plants). Considering that the depth of the substrate and drainage layers was $120 \mathrm{~mm}$, the green roof presents a total depth of $320 \mathrm{~mm}$ for Plectranthus, $370 \mathrm{~mm}$ for Kalanchoe and $220 \mathrm{~mm}$ for Sedum in February. As shown on Tab. 2, k-values of the green roof differed according to the plant species. Sedum k-value is 3 to 4 -fold lower than that of Kalanchoe and Plectranthus. This coincides with the previous results and strengthens the view that Sedum presents the greatest energy performance as compared to Plectranthus and Kalanchoe.

\section{Conclusion}

This study aimed to evaluate for the first time the thermal and energy performance of an extensive green roof in an Indian Ocean area under a tropical humid climate. Our results showed that the green roof induced a significant decrease in temperature fluctuations between the green roof surface and the green roof at the depth of $120 \mathrm{~mm}\left(6.7 \pm 0.1^{\circ} \mathrm{C}\right)$. Each plant also contributed to a low heat flux exchange through the green roof. Sedum presented an average heat flux exchange of $1.4 \pm 0.3 \%$ as compared to Plectranthus $(2.3 \pm 0.2 \%)$ and Kalanchoe $(2.2 \pm 0.4 \%)$. As the energy performance of a green roof mainly depends on its ability to reduce the heat gain, we compared the values of heat gain/loss per meter square over all the five months of experimentation. It was found that Sedum green roof led to a higher heat restitution rate with $63 \%$, than for Plectranthus (54\%) and Kalanchoe (51\%). Regarding the thermal parameters, the green roof with Sedum presented a U-value significantly lower than with Plectranthus and Kalanchoe species. Consequently, Sedum green roof was also characterized by the highest thermal resistance value. Finally, k-value of Sedum green 
roof was much lower than that for Kalanchoe and Plectranthus. To conclude, this study has evaluated for the first time the thermal and energetic performance of a green roof in an Indian Ocean area. Our results contribute to highlight Sedum benefits for a vegetated roof in such an area. Further investigations will be needed to assess if the green roof technology provides a very effective solution for building energy savings in cities under a tropical humid climate.

\section{Acknowledgements}

We gratefully acknowledge SAPEF Company for its contribution to the green roof development and financial support. We also thank the European Union, the French Ministry of Education and Research, and the University of La Reunion for financially supporting our work.

\section{References}

Castleton, H.F., Stovin, V., Beck, S.B.M., Davison, J.B., 2010. Green roofs: building energy savings and the potential for retrofit. Energy and Buildings. 42(10), 1582-1591.

Feng C., Meng Q., Zhang Y., 2010. Theoretical experimental analysis of the energy balance of the extensive green roofs. Energy and Buildings. 42, 959-965.

Getter K.L., Bradley Rowe D., Cregg B.M., 2009. Solar radiation intensity influences extensive green roof plant communities. Urban Forestry and Urban Greening. 8(4), 269-281.

Kumar R., Kaushik S.C., 2005. Performance evaluation of green roof and shading for thermal protection of buildings. Building and Environment. 40(11), 1505-1511.

Lazzarin R.M., Castellotti F., Busato F., 2005. Experimental measurements and numerical modelling of a green roof. Energy and Buildings. 37(12), 1260-1267.

Liu K., Baskaran B., 2003. Thermal performance of green roofs through field evaluation. In: Proceedings for the first North American green roof infrastructure conference, awards, and trade show. pp. 1-10.

Lui K., Minor J., 2005. Performance evaluation of an extensive green roof. In: Greening Rooftops for Sustainable Communities, Washington, DC.

MacIvor J.S., Lundholm J., 2011. Performance evaluation of native plants suited to extensive green roof conditions in a maritime climate. Ecological Engineering. 37(3), 407-417.

Niachou, A., Papakonstantinou, K., Santamouris, M., Tsangrassoulis, A., Mihalakakou, G., 2001. Analysis of the green roof thermal properties and investigation of its energy performance. Energy and Buildings. 33(7), 719-729.

Ould-Boukhitine S.E., Belarbi R., Jaffal I., Trabelsi A., 2011. Assessment of green roof thermal behavior: a coupled heat and mass transfer model. Building and Environment. In Press.

Palomo E., 1999. Roof components models simplification via statistical linearization and model reduction techniques. Energy and Buildings. 29(3), 259-281.

Spala A, Bagiorgas HS, Assimakopoulos MN, Kalavrouziotis J, Matthopoulos D, Mihalakakou G., 2008. On the green roof system. Selection, state of the art and energy potential investigation of a system installed in an office building in Athens, Greece. Renewable Energy. 33(1), 173-177.

Theodosiou, T.G., 2003. Summer period analysis of the performance of a planted roof as a passive cooling technique. Energy and Buildings. 35(9), 909-917. 
Wong N.H., Cheong D.K.W., Yan H., Soh J., Ong C.L., Sia A., 2003a. The effect of rooftop gardens on energy consumption of a commercial building in Singapore. Energy and Buildings. 35, 353-64.

Wong N.H., Chen Y., Ong C.L., Sia A., 2003b. Investigation of thermal benefits of rooftop garden in the tropical environment. Building and Environment. 38, 261-70. 